\title{
Mobile Assisted Language Learning (MALL): Trends from 2010 to 2020 Using Text Analysis Techniques
}

\author{
Panagiotis Arvanitis \\ Aristotle University of Thessaloniki \\ Penelope Krystalli
}

Aristotle University of Thessaloniki

\begin{abstract}
Throughout the decade of 2010-2020, the widespread use of mobile devices of any type (smartphones, tablets) has encouraged and strengthened their use in different learning processes and in different ways. Latest improvements in devices' processing power, in storage capacity, in memory allocation, in wireless connectivity, in GPS and in Bluetooth capabilities, has led to their wider integration and smoother use in the field of learning and in the field of language learning as well. This study examined the trend of a large number of academic studies concerning Mobile Assisted Language Learning (MALL) using text analysis techniques and tools, published in the decade 2010-2020. Over three hundred and forty (340) publications such as journal articles, conferences proceedings papers, books chapters and books were retrieved and analyzed. The preliminary analysis presents the main characteristics and the research trends of this decade and discuss how the field of mobile assisted language learning has evolved in these years.
\end{abstract}

Keywords: mobile language learning, MALL, technology enhanced language learning, mobile devices, language learning

\section{Introduction}

\section{The era of Mobile Learning}

The ever-increasing use of portable and wireless devices and technologies, such as mobile phones, laptops and tablet PCs, Wi-Fi, Bluetooth, wireless LAN, GPS, iPODs, 3G - 5G and satellite systems, enable today's user to access any type of educational material from anywhere and at any time. From the first mobile phone (Motorola DynaTAC 8000X), built in 1973 to the present day, both the cost and shape of mobile devices have been reduced while their power, speed, memory and functionality have been increased. Thanks to these features, mobile devices offer unique possibilities for student-centered approaches to teaching.

Furthermore, mobile devices allow the implementation of innovative teaching practices that we cannot usually experience with other learning tools. They give teachers and learners the opportunity to access educational resources anywhere and anytime, and to participate in new learning situations in different spaces and not just in a frozen school space. Certainly, as Crompton (2013) points out, wireless communication technologies have played an important 
role, without which, mobile learning (m-learning) would not exist. The characteristics of mobile devices that Klopfer et al. (2002) believe may be beneficial for education are portability, social interactivity, context sensitivity, connectivity, and personalization. Indeed, mobile devices, thanks to their portability, offer the possibility of learning without spatiotemporal limitations, use the possibilities offered by mobile wireless technologies for easy access to information, promote the development of digital literacy and offer possibilities. for independent learning (Zaranis et al., 2013).

Defining m-Learning is not an easy task to do, as different terms and concepts are involved. Initially, MA was primarily described as the use of mobile devices in learning such as mobile phones, tablet computers, handhelds and personal digital assistants. was primarily described as the use of mobile devices in learning such as mobile phones, tablet computers, handhelds, and personal digital assistants. In the literature, definitions have been formulated that emphasize technology, others that compare traditional to m-learning, and others that focus on the student. As Taylor (2006) pointed out m-Learning can be understood in a variety of ways, depending on the element that we focus on: learning through mobile terminals, learning with students that are on the move and learning through mobile content. Therefore we can find definitions which focus on the technological, educational component or combination of both of them such as El-Hussein's \& Cronje's (2010) definition : "any type of learning that takes place in learning environments and spaces that take account of the mobility of technology, mobility of learners and mobility of learning".

O’Malley et al. (2005), have defined m-Learning from the learner's perspective as "any sort of learning that happens when the learner is not at a fixed, predetermined location, or learning that happens when the learner takes advantage of learning opportunities offered by mobile technologies". Conde et al.(2008) have defined m-learning by situating it between e-Learning and ubiquitous learning (u-Learning): "m-Learning" can be understood as an evolution of eLearning which allows students to exploit the advantages of mobile technologies in order to support their learning process and constitutes the first step towards the creation of ubiquitous learning". Although the definitions differ, researchers agree on the basic characteristics of mlearning, considering that it is characterized by the ability to learn (Devaud \& Burton, 2012), to be spontaneous, personalized (Karsenti et al., 2013) and ubiquitous (Miangah \& Nezarat, 2012).

Empirical research conducted at all three levels of education has also found that mobile learning contributes to the development of critical thinking and initiative, increases collaboration between students as well as between teachers and students, enables the teacher for immediate feedback. and assessment, gives access to information everywhere and at any time, prepares students for professional reality, promotes the creation of student communities around the world, personalizes learning, gives educational opportunities to those who cannot access good quality education, and reduces school costs (UNESCO, 2013).

\section{The era of Mobile Assisted Language Learning}

The term Mobile Assisted Language Learning (MALL) was coined by Chinnery (2006), who argued that mobile devices could be used as pedagogical tools for language learning. However, research and publications related to the use of mobile devices in foreign language teaching / learning have been recorded since 1994 (Burston, 2013). 
The main advantages of MALL that have been recorded in the literature can be summarized as follows: it enables students to create their own learning framework in terms of time, place and how they will use online information and learning material with the consequence that their education is independent, self-directed and autonomous (Burston, 2013). It has also been found that the use of mobile devices in foreign language teaching / learning enhances the motivation for learning as it facilitates alternative non-traditional teaching methods (Kukulska-Hulme, 2009; Karsenti et al., 2013). According to the researchers, MALL can be used in order to:

- enhance the motivation for learning through the use of technology familiar to students such as smartphones and tablets.

- give more opportunities to students to develop all six communication skills: comprehension and production of written speech, comprehension and production of spoken language, aural interaction and aural and written mediation

- encourage the use of the target language as a unique means of communication

- facilitate the teaching process through exploring, analyzing, discovering and choosing activities that make sense in the real world

- enhance any type of interaction between real and virtual environments, between students in the same classroom but also with students in another classroom inside and outside school boundaries

- promote learning in a pleasant way.

The model that is commonly applied is the BYOD model (acronym for "Bring Your Own Device"), that comes to provide solutions to schools that face logistical infrastructure problems and do not have the ability to purchase mobile devices. Students are required to bring their own devices and all that is required to implement it is a high-speed internet connection. This model has significant advantages for the school unit: it reduces the purchase costs of the devices and their maintenance costs. It has also been observed that students are very careful in the way they handle technology as it is their own device.

\section{Research methodology}

The present study examined the decade's 2010-2020 trends of substantial number of academic publications in Mobile Assisted Language Learning (MALL) using a set of text analysis techniques and tools. More specifically the study aims to find out: what are the main topics that have been discussed and analyzed during the last decade; what topics seem to be of concern to research today and if the focus of research in MALL has shifted to some specific issues.

In the past years, several researchers have provided very important annotated bibliographies, literature reviews or other analytic studies of MALL and tried to explore the boundaries of this field. To mention a few: Kukulska-Hulme and Shield (2008), Burston (2013, 2014a, 2014b), Hwang \& Tsai (2011), Hung \& Zhang (2011), Viberg \& Grönland (2012) and Duman et al. (2015).

For the purposes of the study, over three hundred and forty (340) published studies such as journal articles, conferences' proceedings papers, book chapters, and books were retrieved and analyzed by their year of publication, title, and topic. Furthermore, in order to limit the results of the research, we had the following criteria: 
academic studies that were published between 2010 and 2020 (until August 2020),

academic studies that were written in English language,

academic studies that contained only the terms "mobile language learning", "MALL", "mobile devices and language learning",

academic studies belonging to a specific publication type such as journal paper, article in conference proceedings, book chapter or book. Any other type of publication such as phd thesis, book, journal or software reviews or other editorial texts were all excluded from this study.

The process followed was designed to be as simple as possible and had some basic steps. Utilizing the Google scholar, a systematic search was made for each year using only the searching terms, mentioned above. Then, for each search, all the results that had at least a "cited by 5 " indicator were marked. Then, the full citation's information both in APA style and Bibtext format extracted using the "Cite" feature provided by Google Scholar. All citations were stored in detail in excel files and after that their title extracted by year.

All the collected titles stored in 11 separated text/documents files (one for each year) and then inserted as corpus, both in voyant-tools, a web-based reading and analysis environment for digital texts (http://voyant-tools.org), and in wordsmith tools, a text analysis software tool (https://lexically.net/wordsmith), for further processing. All titles were classified by their topic using the seventeen topics proposed by Dunan et al. (2015), with an addition of three more (noted 18, 19, 20) as shown below.

\begin{tabular}{ll}
\hline \hline 1. Vocabulary & 11. Instructional design \\
\hline 2. Grammar & 12. Identity/Sense of community \\
\hline 3. Listening & 13. Usability \\
\hline 4. Speaking/Pronunciation & 14. Potential uses/Drawbacks \\
\hline 5. Reading & 15. Interaction/Collaboration \\
\hline 6. Writing & 16. Perception/Attitude \\
\hline 7. Integrated skills & 17. Academic achievement \\
\hline 8. Dictionary use & 18. Apps overview \\
\hline 9. Assessment-evaluation & 19. Learner motivation/autonomy \\
\hline 10. Multimedia use/Design & 20. Literature Overview/Implementation Studies \\
\hline \hline
\end{tabular}




\section{Data collected analysis}

A preliminary analysis of data collected shows some important findings. Figure 1 shows the total number of published titles, their types, and their distribution over each year.

Based on figure we can easily mention a constant interest and research production of researchers about MALL issues.

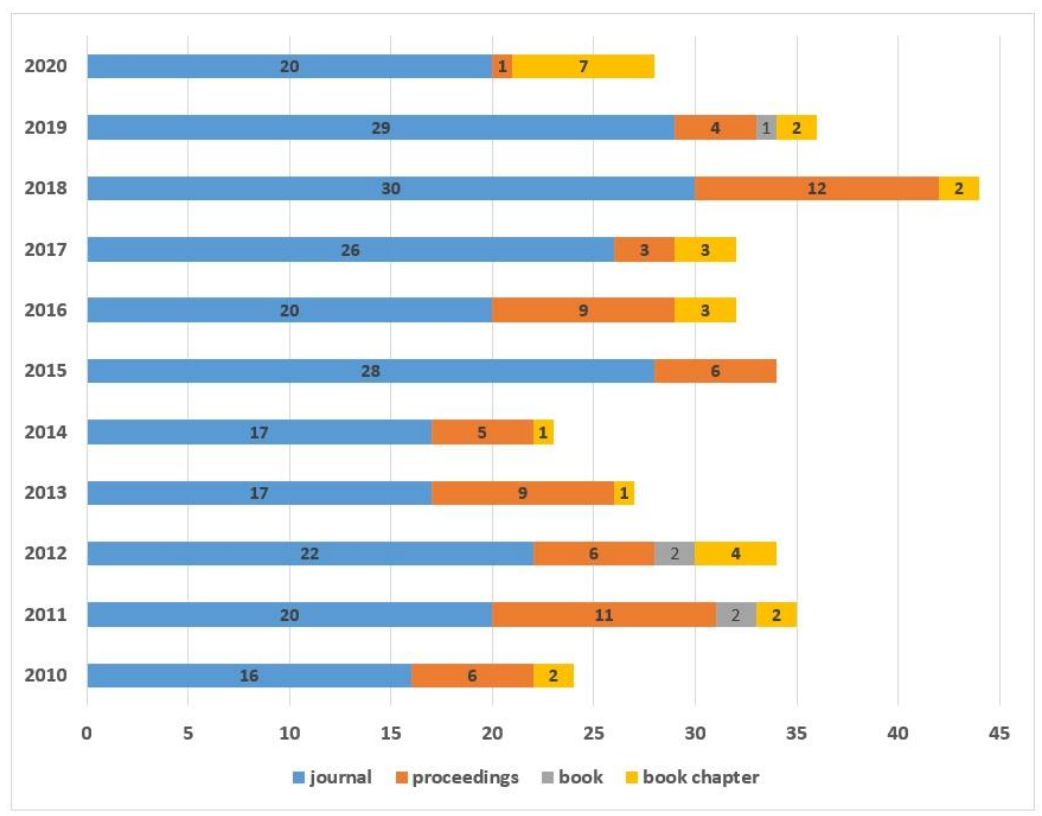

Figure 1 : Published titles, and their research types by year.

Figure 2 shows the types of published studies and their appearance over years.

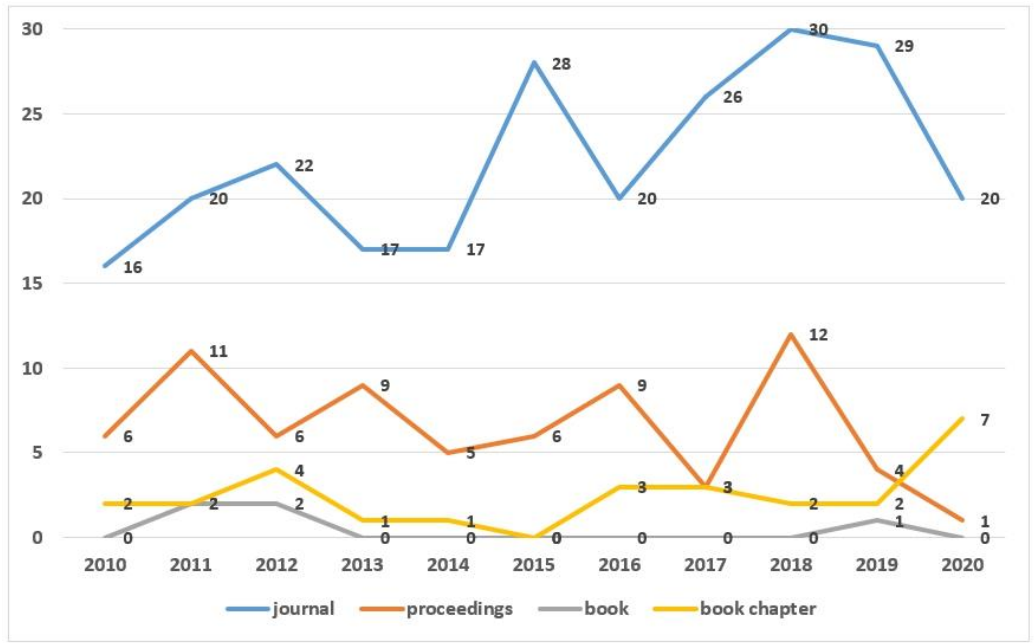

Figure 2 : Studies' types by year 
Table 1 below, demonstrate the 20 topics covered and how they are varied among years.

Table 1. Distribution of topics in the published titles from 2010 to 2020

\begin{tabular}{|c|c|c|c|c|c|c|c|c|c|c|c|}
\hline & $\begin{array}{l}20 \\
10\end{array}$ & $\begin{array}{l}20 \\
11\end{array}$ & $\begin{array}{l}20 \\
12\end{array}$ & $\begin{array}{l}20 \\
13 \\
\end{array}$ & $\begin{array}{l}20 \\
14\end{array}$ & $\begin{array}{l}20 \\
15\end{array}$ & $\begin{array}{l}20 \\
16\end{array}$ & $\begin{array}{l}20 \\
17\end{array}$ & $\begin{array}{l}20 \\
18\end{array}$ & $\begin{array}{l}20 \\
19\end{array}$ & $\begin{array}{l}20 \\
20\end{array}$ \\
\hline $\begin{array}{l}\text { Literature } \\
\text { Overview/ } \\
\text { Implementation } \\
\text { Studies }\end{array}$ & - & 1 & 4 & 2 & 2 & 1 & 4 & 4 & 7 & 12 & 2 \\
\hline $\begin{array}{l}\text { Learner } \\
\text { engagement/moti } \\
\text { vation/ autonomy }\end{array}$ & - & - & - & - & - & 3 & 3 & - & 1 & 3 & 3 \\
\hline $\begin{array}{l}\text { Software/app } \\
\text { Review }\end{array}$ & - & - & - & 1 & - & 4 & 6 & 2 & 9 & 3 & 3 \\
\hline $\begin{array}{l}\text { Academic } \\
\text { achievement }\end{array}$ & - & 1 & 1 & - & - & - & 1 & 1 & 1 & - & - \\
\hline $\begin{array}{l}\text { Perception/Attitu } \\
\text { de }\end{array}$ & 2 & 3 & 2 & 8 & 3 & 3 & 4 & 2 & 10 & 4 & 7 \\
\hline $\begin{array}{l}\text { Interaction/Colla } \\
\text { boration }\end{array}$ & - & - & 2 & 1 & 2 & 2 & - & - & 1 & - & - \\
\hline $\begin{array}{l}\text { Potential } \\
\text { uses/Drawbacks }\end{array}$ & 2 & 4 & 2 & 3 & 1 & 5 & 1 & 4 & 1 & - & - \\
\hline Usability & 4 & 5 & - & 3 & 2 & 4 & 2 & 1 & 3 & - & - \\
\hline $\begin{array}{l}\text { Identity/Sense of } \\
\text { community }\end{array}$ & - & - & - & 1 & 2 & - & - & - & - & - & - \\
\hline $\begin{array}{l}\text { Instructional } \\
\text { design }\end{array}$ & 1 & 1 & 1 & - & 2 & 3 & 2 & - & - & 1 & - \\
\hline $\begin{array}{l}\text { Multimedia } \\
\text { use/Design }\end{array}$ & - & 3 & 6 & 3 & 3 & - & - & 3 & 1 & 2 & 3 \\
\hline $\begin{array}{l}\text { Assessment/eval } \\
\text { uation }\end{array}$ & 1 & - & 3 & - & 1 & 1 & 2 & 1 & 1 & - & - \\
\hline Dictionary use & - & - & - & - & 2 & - & - & - & - & - & - \\
\hline Integrated skills & 4 & 6 & 3 & 1 & 1 & 1 & 2 & 4 & 3 & 1 & 4 \\
\hline Writing & - & 1 & 3 & g- & - & 2 & - & 2 & - & - & 1 \\
\hline Reading & - & 2 & 1 & 1 & 1 & - & - & 1 & 1 & 1 & - \\
\hline $\begin{array}{l}\text { Speaking / } \\
\text { Pronunciation }\end{array}$ & - & - & 1 & - & - & 2 & 4 & 3 & - & 5 & 2 \\
\hline Listening & 2 & 3 & 1 & 2 & 1 & - & 1 & - & 1 & - & - \\
\hline Grammar & 3 & - & - & - & - & - & - & - & - & 1 & 2 \\
\hline Vocabulary & 5 & 5 & 4 & 1 & - & 3 & - & 4 & 4 & 2 & 1 \\
\hline
\end{tabular}

A textual overview of the current corpus with text analysis tools reveals the followed information. The corpus contains 11 text files/documents with 4,321 total words and 810 unique word forms. Most frequent words in the corpus were: "learning" (347), "mobile" (305), 
"language" (281), "assisted" (205), "english" (52), "students" (47), "mall" (46), "efl (41), "learners" (38), "vocabulary" (33) as shown in table 2.

Table 2 : Most frequent words

\begin{tabular}{|c|c|c|c|c|c|}
\hline Term & Count & Term & Count & Term & Count \\
\hline learning & 347 & education & 15 & effect & 10 \\
\hline mobile & 305 & phones & 15 & higher & 10 \\
\hline language & 281 & teaching & 15 & $\begin{array}{l}\text { perspective } \\
\mathrm{s}\end{array}$ & 10 \\
\hline assisted & 205 & attitudes & 14 & phone & 10 \\
\hline english & 52 & based & 14 & self & 10 \\
\hline students & 47 & chinese & 14 & student & 10 \\
\hline mall & 46 & context & 14 & trends & 10 \\
\hline efl & 41 & learner & 14 & writing & 10 \\
\hline learners & 38 & classroom & 13 & application & 9 \\
\hline $\begin{array}{l}\text { vocabular } \\
y\end{array}$ & 33 & devices & 13 & approach & 9 \\
\hline using & 28 & $\begin{array}{l}\text { application } \\
\mathrm{s}\end{array}$ & 12 & listening & 9 \\
\hline use & 26 & college & 12 & perspective & 9 \\
\hline study & 25 & effects & 12 & social & 9 \\
\hline review & 23 & $\begin{array}{l}\text { perception } \\
\mathrm{s}\end{array}$ & 12 & speaking & 9 \\
\hline $\begin{array}{l}\text { technolog } \\
y\end{array}$ & 20 & skills & 12 & tool & 9 \\
\hline foreign & 17 & esl & 11 & & \\
\hline analysis & 16 & reading & 11 & & \\
\hline apps & 16 & second & 11 & & \\
\hline research & 16 & computer & 10 & & \\
\hline case & 15 & design & 10 & & \\
\hline
\end{tabular}

Table 3, shows other distinctive words, compared to the rest of the corpus, for each examined year.

Table 3 : Distinctive words by year.

\begin{tabular}{cl}
\hline \hline 2010 & $\begin{array}{l}\text { supporting (2), meaning (2), Ims (2), phones (5), cell (3), taught (2), recording (2), making (2), } \\
\text { commonly (2), effective (2) }\end{array}$ \\
\hline 2011 & $\begin{array}{l}\text { podcast (4), podcasting (3), networking (2), familiar (2), contexts (2), phones (4), literature (2), } \\
\text { elementary (2), designing (2) }\end{array}$ \\
\hline 2012 & $\begin{array}{l}\text { japanese (2), trends (5), analysis (6), video (2), phones (4), podcasting (2), educational (2) } \\
\text { reuse (2), implementing (2), usage (2), facebook (2), challenges (2), resources (2), informal } \\
\text { (2), cross (2) }\end{array}$ \\
\hline 2014 & needs (2), I2 (2), framework (2) \\
\hline 2015 & $\begin{array}{l}\text { smartphones (4), task (3), sociocultural (2), pp (2), ecological (2), skill (3), engineering (2), } \\
\text { effective (2) }\end{array}$ \\
\hline 2016 & field (2), strategies (2), model (2), iranian (4), teachers (3) \\
\hline
\end{tabular}




\begin{tabular}{cl}
\hline $\mathbf{2 0 1 7}$ & wechat (2), success (2), teaching (4), perspectives (4) \\
\hline $\mathbf{2 0 1 8}$ & $\begin{array}{l}\text { usage (3), memrise (2), wechat (2), smartphones (2), application (4), teaching (5), systematic } \\
\text { (2), smart (2), I2 (2) }\end{array}$ \\
\hline $\mathbf{2 0 1 9}$ & $\begin{array}{l}\text { class (4), knowledge (2), experimental (2), perception (3), systematic (2), literature (2), } \\
\text { implementation (2) }\end{array}$ \\
\hline $\mathbf{2 0 2 0}$ & understanding (2), engaging (2), exploring (3), whatsapp (2), students'attitudes (2) \\
\hline
\end{tabular}

Figures 3 and 4 demonstrate line graphs depicting the word's occurrence across the corpus. As mentioned above the most frequent words contained in the published titles are : "learning; "mobile"; "language"; "assisted", "english", "students", "mall”, "efl"; l"earners"; "vocabulary".

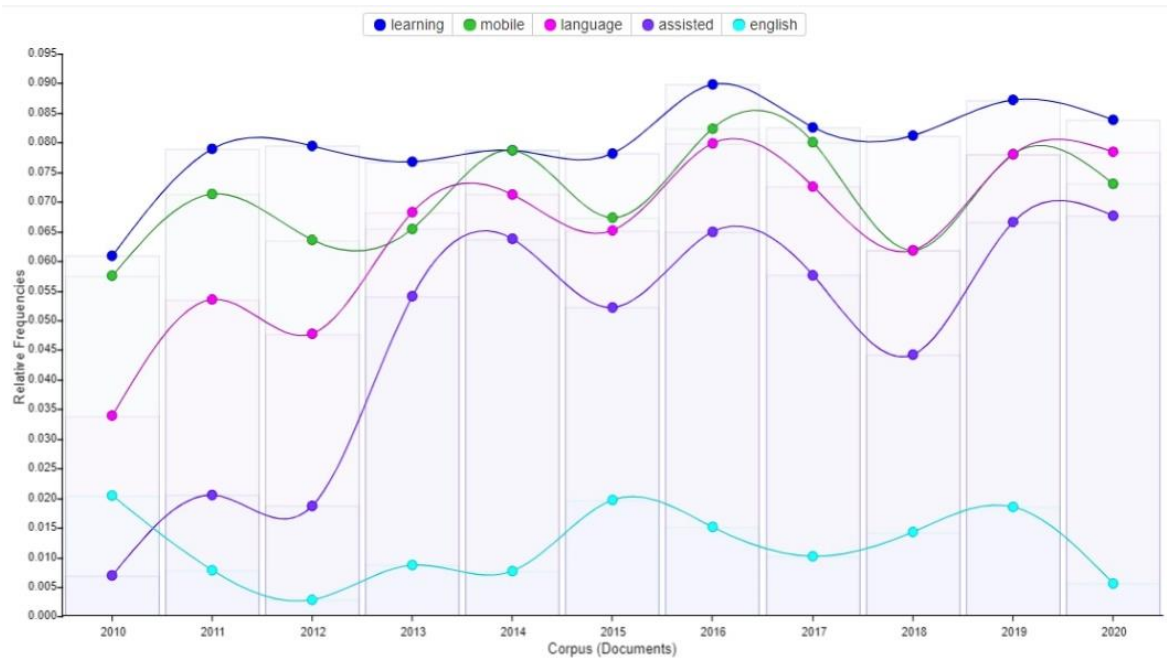

Figure 3 : Trends of a word's occurrence across the corpus

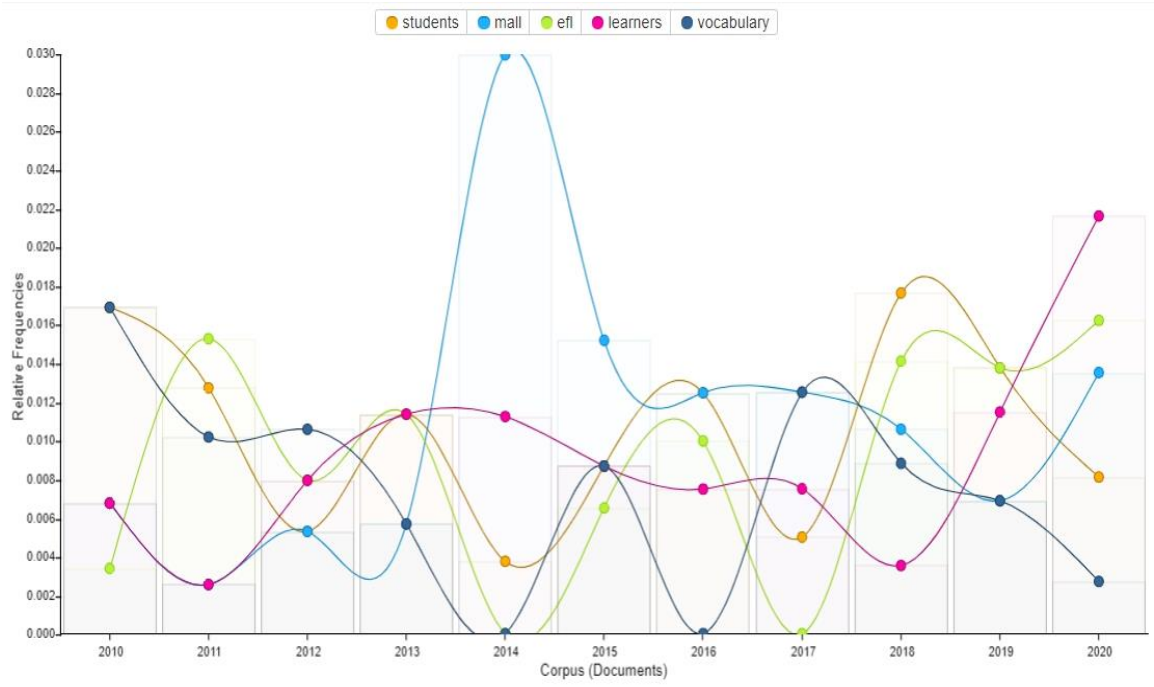

Figure 4 : Trends of a word's occurrence across the corpus 


\section{Conclusion}

It becomes obvious that a short analysis based only on the published titles which does not include the abstracts, or the main texts of these studies is not complete. But it can give us some important clues as to the questions we have asked. All the preliminary findings of this study highlighted a great interest and a steady preoccupation of researchers about MALL issues over these ten years.

The main topics that Duman et al. (2015) identified in their research years ago, remain the same with minor changes. Topics such as Speaking/Pronunciation skills, Listening skills, Vocabulary skills, Perception/Attitude still remains vibrant with the addition of newer topics such as Learner engagement/motivation/autonomy.

Topics related to software and apps overview and presentation or their experimental implementation in specific language teaching conditions also played an important role. This can be easily explained by taking into consideration the large number of mobile apps that have emerged in the last decade dealing with language learning. Terms such as: "mobile", "students", "learners", "technology", "apps", "education”, "teaching”, “attitudes", "context”, "classroom”, "devices", "perceptions", "skills, "design”, seem to be at the center of researchers' interest. A more detailed research and analysis will be conducted in the near future, and will concern the abstracts of these published studies as well.

in conclusion faced in a digitally globalized world, “... an increasing number of learners are learning foreign languages outside a formal and structural classroom-based education" (Arvanitis, 2019). This significantly affects the research and implementation studies of MALL and leads us to better explore and understand the learners/users' needs.

\section{References}

[1] Arvanitis, P. (2019). Self-Paced Language Learning Using Online Platforms. In M. Dressman \& R. W. Sadler (Eds.), Handbook of Informal Language Learning. pp. 171138, Oxford, UK: John Wiley \& Sons Ltd. DOI:10.1002/9781119472384.

[2] Burston, J. (2013) Mobile-assisted language learning: A selected annotated bibliography of implementation studies 1994-2012. Language Learning \& Technology, 17(3): 157-225.

[3] Burston, J. (2014a) The reality of MALL project implementations: Still on the fringes. CALICO Journal, 31(1): 43-65.

[4] Burston, J. (2014b) Twenty years of MALL project implementation: A meta-analysis of learning outcomes. ReCALL, 27(1): 1-17.

[5] Chinnery, G. (2006). Emerging technologies going to the MALL: mobile assisted language learning. Language Learning \& Technology, 10.

[6] Conde, M. Á, Muñoz, C., \& García, F. J. (2008). mLearning, the first step in the learning process revolution. International Journal of Interactive Mobile Technologies (iJIM), 2 (4), 61-63.

[7] Crompton, H. (2013). A historical overview of mobile learning: Toward learnercentered education. In Zane L. Berge \& Lin Muilenbury (Eds.), Handbook of Mobile Learning (3-14). New York, Routledge.

[8] Devaud, P., \& Burton, S. (2012). Migrer des ordinateurs aux tablettes. Centre fri-tic. https://edudoc.ch/record/105130/usage?ln=fr 
[9] Duman,G., Orhon, G., \& Gedik, N. (2015). Research trends in mobile assisted language learning from 2000 to 2012. ReCALL, 27, pp 197-216 doi:10.1017/S0958344014000287.

[10] El-Hussein, M.O.M., \& Cronje, J.C. (2010). Defining Mobile Learning in the Higher Education Landscape. Educational Technology \& Society, 13/3 : 12-21.

[11] Hung, J. L. and Zhang, K. (2012) Examining mobile learning trends 2003-2008: A categorical metatrend analysis using text mining techniques. Journal of Computer Higher Education, 24: 1-17.

[12] Hwang, G. J. and Tsai, C. C. (2011) Research trend in mobile and ubiquitous learning: A review of publications in selected journals from 2001 to 2010. British Journal of Education Technology, 42(4): E65-E70.

[13] Karsenti, T. \& Fievez, A. \& Collin, S. \& Simard, S. \& Dumouchel, G. \& Giroux, P. \& Rasmy, A. \& Morin, M. \& Dupuis, A. \& Boily, A. \& Roy, N. (2013). L'iPad à l'école: usages, avantages et défis. Résultats d'une enquête auprès de 6057 élèves et 302 enseignants du Québec (Canada). Montréal, QC: CRIFPE.

[14] Klopfer, E., Squire, K. \& Jenkins, H. (2002). Environmental detectives. PDAs as a Window into a virtual simulated world. Proceedings of IEEE International Workshop on Wireless and Mobile Technologies in Education, 95-98.

[15] Kukulska-Hulme, A. (2009). Will mobile learning change language learning? In ReCALL, 21(2), 157- 165.

[16] Kukulska-Hulme, A. and Shield, L. (2008). An overview of mobile assisted language learning: From content delivery to supported collaboration and interaction. ReCALL, 20(3) pp. 271-289.

[17] Miangah, T.M. \& Nezarat, A. (2012). Mobile-Assisted Language Learning. International Journal of Distributed and Parallel Systems (IJDPS) 3/1: 309-319.

[18] O'Malley, C. et al. (2005). MOBIlearn-Guidelines for Learning/Teaching/Tutoring in a Mobile Environment. Nottingham: University of Nottingham, 82 p. (Pedagogical Methodologies and Paradigms, WP). http://hal.archivesouvertes.fr/docs/00/69/62/44/PDF/OMalley-2005.pdf

[19] Taylor, J. (2006). Evaluating mobile learning: What are appropriate methods for evaluating learning in mobile environments? In M. Sharples (Ed.), Big issues in mobile learning (pp. 25-27) University of Nottingham.

[20] UNESCO, (2013). Principes directeurs de l'UNESCO pour l'apprentissage mobile [On line]. https://unesdoc.unesco.org/ark:/48223/pf0000219661.

[21] Viberg, O. and Grönlund, Å. (2012) Mobile assisted language learning: A literature review. mLearn 2012. 11th World Conference on Mobile and Contextual Learning, Helsinki, Finland.

[22] Zaranis, N., Kalogiannakis M. \& Papadakis, S. (2013). Using Mobile Devices for Teaching Realistic Mathematics in Kindergarten Education. Creative Education, 4/7A1: 1-10. 